\section{Modelling fishing location choice and spatial behaviour of fishers near a marine protected area}

\author{
Riad Mohammed Sultan \\ University of Mauritius, Reduit, Mauritius
}

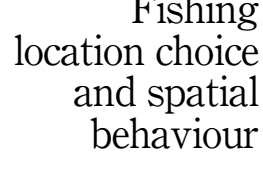

Fishing nd spatial behaviour

Received 13 October 2019 Revised 11 December 2019 19 July 2020

16 October 2020
Accepted 18 October 2020

\begin{abstract}
Purpose - This study investigates whether higher catch rates near a marine protected area (MPA), and/or in other fishing areas within a choice set, attract more fishers. A survey conducted in the fishing grounds near an MPA located in south east of Mauritius in the Indian Ocean shows concentration of fishers in regions with lower catch rates. This contrasts with the predictions of the "fishing the line" hypothesis and the ideal free distribution (IFD) that fishers are likely to be attracted near the MPA with higher resource abundance.

Design/methodology/approach - Using the random utility model as the framework and the random parameter logit (RPL) model, the study attempts to explain spatial behaviour of fishers. Expected catch and catch variability are modelled using the Just and Pope (JP) production function. The study also estimates effort elasticities with respect to expected catch and catch variability and simulates the relocation of effort from area closure.

Findings - The paper concludes that higher catch does attract fishers but is a partial and very restrictive explanation of fishers' behaviour. The "fishing the line" hypothesis does hold to some extent, but it should not be taken for granted that rising catch rates in adjacent waters will increase fishing pressure. The paper concludes that factors such as catch variability, distance from homeport to fishing ground, potential physical risk and attitudes towards risk of fishers affect spatial behaviour of fishers and should be considered for the placement and size of MPAs. The study also finds that the responsiveness of effort to catch rates is lowest in areas which are already heavily fished and easily accessible.

Practical implications - The identification of fishing areas as complements (when fishing in one area increases fishing effort in another) and substitutes is valuable information for determining the placement and size of an MPA. A larger reserve is likely to have more displacement effect in this case than a smaller one. Therefore, a small or a network of a small reserve may be appropriate. The premise to select the site and size of the reserve is to avoid overconcentration of fishers in alternative fishing areas, which can be vulnerable to excessive fishing and unintended effects from fishers.

Originality/value - The paper contributes to an understanding of fishing behaviour and its impact on the configuration of marine reserves. It discusses the importance of effort elasticities to determine the placement and size of an MPA. Studies on this topic are very scanty in the Indian Ocean region. It also shows the application of location choice model, the RPL model and the JP production function in the fisheries sector for a small island. Keywords Marine protected areas, Fishers' behaviour, Effort elasticities, Location choice, Random parameter logit model
\end{abstract}

Paper type Research paper

(C) Riad Mohammed Sultan. Published in Marine Economics and Management. Published by Emerald Publishing Limited. This article is published under the Creative Commons Attribution (CC BY 4.0) licence. Anyone may reproduce, distribute, translate and create derivative works of this article (for both commercial and non-commercial purposes), subject to full attribution to the original publication and authors. The full terms of this licence may be seen at http://creativecommons.org/licences/by/4.0/ legalcode

TO BE ADDED LATER

This paper originates from the $\mathrm{PhD}$ thesis entitled,' Marine Protected Areas in the Management of Artisanal Fisheries' at the University of Cape Town. The author is greatly indebted to Prof Anthony Leiman, for his constant reviews, insights and suggestions for this work. Financial support from the Swedish International Development Cooperation Agency (SIDA)/International Development Research Centre (IDRC), University of Cape Town and the Centre for Environment Economics and Policy in Africa (CEEPA)'s research grant under the SIDA/IDRC is gratefully acknowledged. The author would also like to thank the reviewers of this journal for their valuable comments on the paper. Any errors and omissions are solely the responsibility of the author.

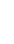


MAEM

4,1

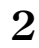

\section{Introduction}

There is widespread agreement that marine protected areas (MPAs) or marine reserves generate conservation benefits (Smith et al., 2005; Lorenzen et al., 2010; Norse et al., 2010; Smith, 2010; Kamil et al., 2017). However, there is an ongoing debate as to whether they improve long-term harvests for fisheries (Smith et al., 2006; Pérez-Ruzafa et al., 2017; Lloret et al., 2018). In the years that follow its creation, it is expected that an MPA will increase the abundance of fish, and that this increase will lead to spillovers in the forms of adult and juvenile migration and the export of larvae to adjacent areas. These are important benefits to fisheries and are used to assess the effectiveness of marine reserves over a defined period of time (Chapman and Kramer, 1999; Gell and Roberts, 2003; Forcada et al., 2009; Norse, 2010; Bellier et al., 2013; Kamil et al., 2017; Lloret et al., 2018).

One of the key arguments against the use of MPAs as a fisheries management tool is that the spillovers simply draw fishing effort to the reserve boundaries (Hopf et al., 2016; PérezRuzafa et al., 2017; Lloret et al., 2018). Such behaviour may impact negatively on marine ecosystems by inducing localised overfishing and altering the habitat in over-concentrated fishing grounds (Hopf et al., 2016). This effort redistribution has been referred to as "fishing the line" (Kellner et al., 2007; van der Lee et al., 2013). The "fishing the line" hypothesis inevitably throws doubt on the effectiveness of marine reserves as remedies to fisheries degradation, since it suggests that fishing pressure is likely to increase in areas near reserves, and the fisheries may fall back to the same condition they were in before the reserve was created (Smith, 2004, 2005; Smith and Wilen, 2003; Daw, 2008; Hopf et al., 2016).

This concern is particularly relevant in the island of Mauritius, which has established MPAs around its coasts since 1983 to protect the habitat for fish species, the diverse marine fauna and flora and the nursing grounds for juvenile marine species (UNDP 2012). The process of establishing new protected areas and expanding existing ones is ongoing, especially as an option for marine spatial planning (Kelleher, 2017; Smith, 2000). However, an aspect currently overlooked is that MPAs also modify the behaviour and effort of artisanal fishermen.

Do fishermen respond to rising catch rates at the border of a marine reserve? This "fishing the line" behaviour is often simply assumed (Cabral et al., 2017). Even if the economic theory predicts that potential rents are squandered in an open access fishery and that fishers will earn normal profits only, fishers' choice of fishing grounds is far more complex than suggested by the simple assumption that rising catch will attract more fishers. When the aim is to assess the distributional impacts of MPA benefits to a specific study site, a before-aftercontrol-impact (BACI) experiment would be most appropriate, comparing variables such as fish density, biomass, size of organisms, species diversity and more importantly fishing effort (for e.g. Halpern, 2003). In many cases, these data are not available and such before-and-after analyses cannot be made. However, a scientific and systematic analysis of fishing effort in the vicinity of the MPA and the factors influencing it can provide insights into whether efforts have been distributed to benefit spillovers.

To shed light on the above question, this study examines the determinants of fishers' location choices in the adjacent waters of the Blue Bay Marine Park (BBMP) in the south-east coast of Mauritius and tests the hypothesis that whether rising catch rates will attract fishers at the border of the BBMP. It also examines other determinants of fishers' location choices, building on work done elsewhere by Bockstael and Opaluch (1983), Eales and Wilen (1986), Campbell and Hand (1999), Bingham et al. (2011), Andersen et al. (2012), Van Putten et al. (2012), Girardin et al. (2016), Dabrowska et al. (2017) and Watson et al. (2018). Once the socioeconomics and trip-related determinants have been established, the study conducts a simulation exercise. This is to calculate the responsiveness of fishing effort with respect to changes in the factors identified as drivers of fishing location choice. The simulation also 
separates the waters surrounding the MPA into those that are complements to it and those fishing areas that are its substitutes and eventually calculates the marginal rates of substitution. This process establishes the opportunity cost of the reserve's creation. Finally, a simulation exercise is undertaken to estimate the expected change in fishing effort should the area of the MPA be increased. Effort displacement is also simulated for the closure of other fishing areas to showcase the issue of spatial connectivity across fishing areas.

\section{A brief review of the fishing literature on spatial choice}

Expectations that fishing effort will be relocated is important for the design and site selection of a marine reserve (Smith 2004; Smith and Wilen 2003; Smith, 2010)). If the aim of the MPA is to protect a breeding site, a rare species, or a recreational site for divers and if the area protected is fairly small, then it may fail in its objectives if fishers target its boundaries. On the other hand, if the reserved area is large relative to the fishable area, a reserve can reduce fishing opportunities, forcing people with limited alternative occupations to abandon fishing altogether.

The details of fisher effort relocation can therefore be crucial since it affects the broader costs and benefits of a reserve: in particular, its impacts on expected catch, catch variance, targeted species and fishing costs. Valcic (2009) makes the point that one may design the appropriate regulations and incentive structures to minimise the impacts of such effort displacement. The starting point is to determine the factors, trip-related and other, influencing fishing location choice.

From both a theoretical and an empirical perspective, fishing is non-random (Gillis et al., 1992). The economic theory goes beyond a simple analysis of effort distribution and adopts a perspective which is consistent with the "ideal free distribution" (IFD) of behavioural ecology (Gillis et al., 1992; Abernethy et al., 2007; Gillis and van der Lee, 2012).

The IFD predicts that, assuming free movement and perfect knowledge, fishing pressure should increase with resource abundance. Ultimately, efforts will be adjusted among fishing areas so as to equalise catch per unit of effort (CPUE) across all areas. In reality, CPUE frequently varies across neighbouring fishing grounds. When there are differential catch rates, factors other than expected catch or revenue may be affecting the fishers' choice of fishing ground (Holland, 2000).

H. S. Gordon's (1954) pioneering paper showed how economic theory has been used to inform fisheries management. It was followed by a number of studies evaluating fishers' behaviours in terms of the economic theory (for example, Wilen, 1976; Eales and Wilen, 1986; Curtis and McConnell, 2004). The economic framework, typically using micro-level analysis of fishers' behaviours and discrete choice models, provided both the theoretical underpinnings and quantitative techniques for a systematic analysis of spatial behaviour in fisheries. Fishers are assumed to choose between finite discrete alternatives, each having a set of possible outputs or closely substitutable inputs. In this respect, there are several key factors which determine site selection.

There have been numerous examples: Wilen (1976) in a study of aggregate behavioural responses concludes that fishers respond to profitability in their long-term decision to enter or exit a fishery. Similarly, Bockstael and Opaluch (1983), in a study of location and species choice of New England fishers, used a utility-based framework to model the micro-level behaviour of fishers and also found that fishers react positively to expected profits. Eales and Wilen (1986) found that expected catch explained the choice of fishing site in the Alaskan Pink Shrimp Fishery, while Campbell and Hand (1999) made a similar observation in the western Pacific tuna fishery.

Bockstael and Opaluch (1983) broadened these insights into fisher behaviour by adding risk as an explanatory variable. Their analysis noted that fishing location choices were negatively affected by risk, modelled by the variance of output. Dupont (1993) expanded this 
MAEM

4,1

4

approach further in the British Columbia salmon fishery. After generating expected profit through price forecasts derived from an autoregressive integrated moving average (ARIMA) model, she found that not only expected seasonal profit and its variability but also expected wealth and its variability were determinants of fishing location choice. Mistiaen and Strand (2000) considered price as a deterministic variable and harvest as a stochastic variable to construct expected profit: using a multinomial logit as well as a random parameter logit (RPL) model for fishers in the North Atlantic fishery, they also found that expected profit and its variability affect locational decisions by fishers.

Since profit is not driven by revenue alone, the economic approach also treats fishing cost as an important driver of fisher behaviour (Girardin et al., 2017, Watson et al., 2018). Fishing cost in turn is strongly linked to distance from homeport to fishing location. Distance travelled to a site is found to negatively influence the likelihood of its selection by Campbell and Hand (1999), Mistiaen and Strand (2000) Berman (2006), Bingham et al. (2011) and Andersen et al. (2012). Campbell and Hand (1999) further noted an elastic response to expected value of catch and an inelastic response in respect to travel cost.

In an uncertain environment, if a particular location is high yielding but has higher than average catch variability, the extent to which it is used will, to a large extent, depend on whether fishers are risk-averse or risk-loving (Mistiaen and Strand, 2000; Eggert and Tveteras, 2004; Eggert and Lokina, 2007; Girardin et al., 2017). According to Smith and Wilen (2005), commercial fishermen are inherently risk-loving; however, this generalisation is clearly an oversimplification. Salas and Gaertner (2004) pointed out that some fishers are willing to sacrifice high catches to minimise personal and economic risk, and a number of empirical studies have concluded that fishers are risk-averse (Dupont, 1993; Mistian and Strand, 2000; Eggert and Lokina, 2007). Discrete choice models, usually modelled by a parametrisation of mean and standard deviation of revenue [1], are one way to infer the degree of risk aversion among fishers. However, this can also be obtained via separate experiments that provide information on risk preferences (Eggert and Martinsson, 2004; Eggert and Lokina, 2007; Brick et al., 2012).

While expected catch rates, risk-related factors, fishing costs and risk attitudes remain as the main determinants of fishing location choices, there are also other factors which have been identified. These are fishers' individual characteristics (Holland and Sutinen 2000; Eggert and Tveteras 2004, Van Putten et al., 2012), fishing equipment and tactical decisions (Eales and Wilen 1986; Salas and Gaertner, 2004; Christensen and Raakjaer, 2006) and site characteristics, including the biophysical ocean and weather conditions (Bingham et al., 2011, Van Putten et al., 2012) and social factors such as rules, institutions, local traditions, cultureand habits (Dow, 2008; van Putten et al., 2012).

\section{Conceptual framework, estimation method and data}

The conceptual framework of this paper is based on the random utility model with a submodel of expected catch following work of Eales and Wilen (1986), Campbell and Hand (1999) and Eggert and Tveteras (2004). The location choice estimation method is the RPL model, also known as the mixed logit model (Train 2009) [2]. As an innovative method, the RPL model is a modified conditional logit model, which relaxes the independence of irrelevant alternatives (IIA) property. The IIA property assumes that the random error component is independent across choices for each decision-maker, and that the change in, or the introduction of, or the elimination of an existing attribute of an alternative would cause proportional changes in the probabilities of the other alternatives, i.e. the ratios of the probabilities would remain unchanged (McFadden, 1974). In this respect, the RPL model accommodates fishers' heterogeneity and is more appropriate for modelling fishing choices (Wilen et al., 2002; Hutton et al., 2004; Abott and Wilen 2011; Tidd et al., 2012). The RPL model's overall explanatory power is given by the likelihood ratio statistic (Pradhan and Leung, 2004). 
Random utility and location choice model

The random utility model follows the work of Bockstael and Opaluch (1983), Smith (2004), Eggert and Tveteras (2004) and Jiménez-Alvarado (2019), among others. When a fisher $i$ makes a choice to fish in a location $j$ from a finite set of $J$ mutually exclusive fishing alternatives $[J=1, \ldots, n]$, his maximum utility $\left(U_{i j}\right)$ has both observed $\left(V_{i j}\right)$ and unobserved $\left(\varepsilon_{i j}\right)$ component. In additive linear form, the utility function is written as follows (McFadden, 1974):

$$
U_{i j}=V_{i j}+\varepsilon_{i j}
$$

The term $\varepsilon_{i j}$, through extreme value distribution, has a zero mean and is uncorrelated across choices, allowing for the IIA property in the choice model. This means that outcome categories are distinct in the eyes of each fisher.

When faced with alternatives $l$ and $j$, the fisher chooses alternative $j$ if $U_{i j}>U_{i l}$ for $l \neq j$. Since the unobserved component for the two alternatives $\varepsilon_{i j}$ and $\epsilon_{i l}$ are random variables, the difference between them is also random. The standard model predicts that the probability that the fisher will choose alternative $j$ is

$$
P\left(Y_{i}=1 \mid X_{i j}, W_{i}\right)=\frac{e^{V_{i j}}}{\sum_{j=1}^{J} e^{V_{i j}}}
$$

where $X_{i j}$ are attributes, which vary across choices, and $W_{i j}$ are the characteristics of the individual whose values are invariant to the choice a fisher makes.

$V_{i j}$ can be further specified as follows:

$$
V_{i j}=\theta Z\left(X_{i j}, W_{i}\right)=X_{i j} \beta+W_{i \gamma}
$$

where $\theta, \beta$ and $\gamma$ are the vectors of coefficients providing information on the marginal utilities with respect to their relevant characteristics.

Assume the indirect utility is a linear function of the mean and variance of profits such that,

$$
V_{i j}=\left(E\left[\mathrm{WEA}_{i}+\mathrm{REV}_{i j}-\mathrm{COS}_{i j}\right], \operatorname{var}\left[\mathrm{WEA}_{i}+\mathrm{REV}_{i j}-\mathrm{COS}_{i j}\right]\right)
$$

where $\mathrm{WEA}_{i}$ is initial wealth, $\mathrm{REV}_{i j}$ is revenue of fisher $i$ to fishing location $j$ and $\operatorname{COS}_{i j}$ is the cost incurred during the trip.

By using a composite price for fish species caught during the trip, Eqn 4 can be converted to a model in which utility is effectively driven by the catch rather than by short-term variations in the prices fetched by individual species. Revenue is defined as follows:

$$
\mathrm{REV}_{i j}=P \times \mathrm{CAT}_{i j}
$$

where $P$ is a composite price index in a multi-fish species environment and assumed to be constant for the period. An important caveat of the composite price index is as follows: some species may be more targeted than others and probably sell at better prices; in this respect, fishers may decide on their locations based on the abundance of a single desirable species rather than on all fish in general, as the use of a composite price index would suggest.

However, the use of catch data is justified on several grounds. First, the aim of the study is to connect fishers' behaviour with the change in catch rates as a result of spillovers from the marine reserve. Using expected catch is consistent with the fact that spillovers are often evaluated in terms of CPUE as a measure of abundance or catch arising from adult and juvenile migration (Chapman and Kramer, 1999; Forcada et al., 2009; Bellier et al., 2013). In many fishing communities, where the most visible measure of output is the catch, there is also a perception that many fishers are not profit maximisers but prefer catch weight maximisation (Herrero and Pascoe, 2003). Abbott and Wilen (2011) further argue that 
MAEM

4,1

simply lumping species together into a single revenue index is not realistic when fishers' behaviour has much to do with catching different species. Price effects can obscure changes in the catch rate following changes in conditions in the fishing grounds. Price variability is also a factor in the decision, but according to Eggert and Tveteras (2004), it is a less important source of risk, as changes occur over a longer time and fishers usually have information on prevailing market prices. For these reasons, prices are non-stochastic and exogenous. Expected catch is therefore the main motivation to fishers at a particular site.

The cost function is based on the cost per trip which is a function of the travel distance from their homeport to the point at which the traps are laid $\left(\mathrm{DIS}_{i j}\right)$ and a unit cost of travelling $c$, again assumed to be constant:

$$
\mathrm{COS}_{i j}=c \times \mathrm{DIS}_{i j}
$$

A fisher's location decision is based on the catch expectation, $E\left(\mathrm{CAT}_{i j}\right)$, and not on the catch actually achieved. Fishers would form expectations about the types of fish species, number of individual fish and weight of the fish that would be caught and variance of catch, $\operatorname{var}\left(\mathrm{CAT}_{i j}\right)$. Utility is positively related to expected catch measured in weight, consistent to the fishing the line hypothesis, such that $\frac{\partial U}{\partial E(\mathrm{CAT})}>0$ and is negatively affected by travel distance from the homeport $\frac{\partial U}{\partial \mathrm{DIS}}<0$.

If fishers are risk-neutral, then only the mean matters; if they are risk-averse, they will make a trade-off between expected catch and variance of catch $\frac{\partial U}{\partial \operatorname{Var}(\mathrm{CAT})}<0$; finally, if they are risk-loving fishers, utility rises with variance of the catch and $\frac{\partial U}{\partial \operatorname{Var}(\mathrm{CAT})}>0$ (Eggert and Martinsson 2004).

In linear form, Eqn 4 reduces to

$$
V_{i j}=\alpha_{0} \mathrm{WEA}_{i}+\alpha_{1} E\left(\mathrm{CAT}_{i j}\right)+\alpha_{2} \mathrm{DIS}_{i j}+\alpha_{3} \operatorname{var}\left(\mathrm{CAT}_{i j}\right)
$$

Eqn 7 can be used to estimate the sensitivity of site choice, i.e. $\alpha_{0}, \alpha_{1}, \alpha_{2}$ and $\alpha_{3}$, with respect to initial wealth, expected catch, travel distance and variability of catch, respectively. Eventually, they can be further used to provide insights into the effect of risk preferences of fishers on fishing location choices.

\section{Operationalising the model: the Just and Pope production function}

One of the main problems faced by location choice models is how to replicate the process of catch expectations formation. It is assumed that fishers' implicitly model expected catch on the basis of past catch rates when they are choosing between different fishing grounds. This study follows Eggert and Tveteras (2004) and models expected catch and variance using the JP production function (Just and Pope, 1979) to estimate the sub-model for expected catch rate and its variability.

Consider the following relationship between the input and output:

$$
y=g(x)+u=g(x)+h(x)^{1 / 2} \varepsilon
$$

where $x$ is a vector of $K$ inputs, $g(x)$ is the mean function (or deterministic portion of the production function), $h(x)$ is the variance function or risk portion and $\varepsilon$ is an exogenous shock with $E(\varepsilon)=0$ and $\operatorname{Var}(\varepsilon)=\sigma_{\varepsilon}^{2}$. The vector of inputs, $x$, influences both mean catch and output risk because $\operatorname{var}(y)=\operatorname{var}(u) \stackrel{\varepsilon}{=} h(x) \sigma_{\varepsilon}^{2}$. A key requirement of the JP method is that there should be no a priori restrictions on the effects of inputs on output risks. In other words, the production function should be general enough to accommodate both increasing and decreasing risks.

Each fisher has to choose only one fishing location per trip among eight alternatives. For the chosen ground, the choice-specific attributes take the expected values of the fisher, as measured by Eqn 9 . The mean function is estimated using ordinary least squares as follows: 


$$
\begin{aligned}
\mathrm{CAT}_{i j t}= & a_{0}+a_{1} \mathrm{HRS}_{i j t}+a_{2}\left(\mathrm{HRS}_{i j t}\right)^{2}+a_{3} \mathrm{NBAS}_{i j t}+a_{4}\left(\mathrm{NBAS}_{i j t}\right)^{2}+\sum_{m=2,10} a_{m} \mathrm{DUM}_{m} \\
& +\sum_{i=2,100} a_{i} \mathrm{DUM}_{i}+u_{i j t}
\end{aligned}
$$
and spatial behaviour

$\mathrm{CAT}_{i j t}$ is the catch, $\mathrm{HRS}_{i j t}$ is hours fished and $\mathrm{NBAS}_{i j t}$ is the number of traps for fisher $i$ at time $t$ in the fishing ground $j . \mathrm{DUM}_{m}$ is a dummy variable representing the month the trip was made, and $\mathrm{DUM}_{i}$ is a dummy variable for each fisher.

The parameters of the variance function are estimated using the predicted residuals from Eqn 9:

$$
\operatorname{var}\left(u_{i j t}\right)=\exp \left(\begin{array}{c}
b_{1} \mathrm{HRS}_{i j t}+b_{2}\left(\mathrm{HRS}_{i j t}\right)^{2}+b_{3} \mathrm{NBAS}_{i j t}+b_{4}\left(N B A S_{i j t}\right)^{2} \\
+\sum_{m=2,10} b_{m} \mathrm{DUM}_{m}+\sum_{i=2,100} b_{i} \mathrm{DUM}_{i}
\end{array}\right)
$$

In the first stage of the estimation, Eqns 9 and 10 are used to calculate the predicted values of catch $\left(\mathrm{ECAT}_{i j t}\right)$ and standard deviation of catch $\left(\mathrm{SDCAT}_{i j t}\right)$. These values are then averaged in each of eight fishing areas (Figure 1) to approximate expectations of catch $\left(\mathrm{ECAT}_{j}\right)$ and standard deviation of catch $\left(\mathrm{SDCAT}_{j}\right)$ This technique implies that the calculated expectations are also assigned to fishers for the non-chosen alternatives, assuming that these alternatives are also available to the fishers (Pradhan and Leung, 2004). Pradhan and Leung (2004) use the mean of expected values of similar size and trip type.

The third area-specific attribute is the depth, measured at the fishing site in metres $\left(\mathrm{DEPTH}_{j}\right)$. The data were collected from Google Maps platform.

A fourth area-specific attribute is the distance travelled from homeport to the fishing locations $\left(\mathrm{DIS}_{j}\right)$ (Campbell and Hand, 1999).

\section{Data}

Study site. The Republic of Mauritius is a set of islands located in the southwest Indian Ocean, with a total land area of $2040 \mathrm{~km}^{2}$. The main island of Mauritius has an area of $1865 \mathrm{~km}^{2}$ and a

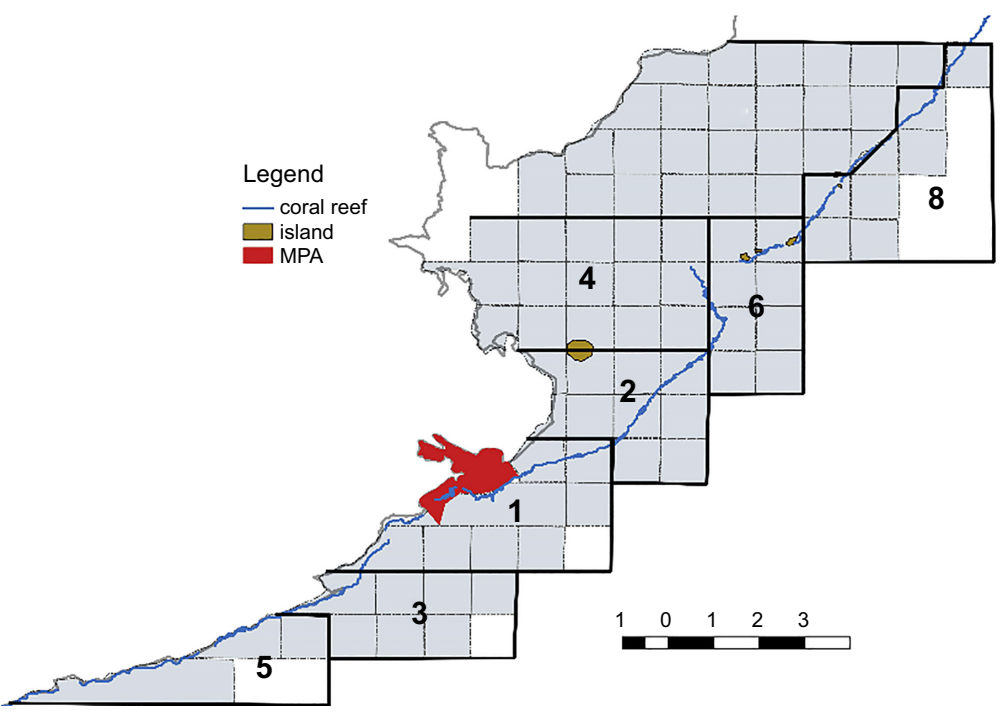

Figure 1. Fishing location grids near the MPA 
MAEM

4,1

8

lagoon area of about $243 \mathrm{~km}^{2}$ (Bhagooli and Kaullysing 2018). The study area comprises of a multispecies-fishing ground of roughly $90 \mathrm{~km}^{2}$ of waters off the south-east coast of island of Mauritius. The site is the biggest lagoon area of the island and is home to $40 \%$ of the island's artisanal fishers.

The area also hosts the Blue Bay Marine Park (see Figure 2), located on the south-east coast of Mauritius, and was declared an MPA and designated a Marine Park in June 2000 under the Fisheries and Marine Resources Act 1998 (Convention on Biological Diversity [CBD], 2016). The total area of the Marine Park currently has an area of 353 hectares $\left(3.53 \mathrm{~km}^{2}\right)$. The water depth in the park varies from 1 to 150 metres (Albion Fisheries Research Centre [AFRC], 2008). The main fish species, which are observed from the fishing grounds, include siganus sutor, naso unicornis, scarrus ghobun and lethrinus nebulous. Other fish species can also be found such as E pinephelus fasciatus kyphosus, lethrinus mahsena, Parupeneus sp., Acanthurus sp, Caranx sp. and Hypseleotris cyprinoides (AFRC 2008). There is no study specifically on spillover from the Marine Park. However, biodiversity inventories show some improvements (Conand et al., 2016). The oceanographic survey conducted in 2010 revealed that the marine biodiversity is higher in the deeper areas of the Blue Bay Marine Park than in the shallow ones (Republic of Mauritius 2010). However, the report also noted that many corals are heavily damaged or eventually dead. Enforcement of the Park falls under the purview of the Blue Bay Marine Park Centre, and there are no enforcement issues highlighted in those inventories reports. A traffic lane provides entry into or passage through the park by motorised boat with a speed not exceeding three knots. Buoys with red and white vertical stripes demarcate the traffic lane. Use of non-motorised boats, fishing, snorkelling, swimming and diving are not allowed in the traffic lane. A ski lane is designated for water skiing, and no other activity is permissible.

Collection of data. To collect and construct the covariates, a questionnaire was prepared and was administered to a sample group of fishers. There are approximately 350 trap fishers in the region of the study, from which 100 fishers, registered with the fishing authority in Mauritius, were randomly selected. For each fisher, data were collected for ten trips per year (averaging one trip per five weeks). For each trip, the interviewer recorded the catch as soon as the fisher reached the fish landing stations. The questionnaire recorded (among other data) the following: (1) total catch in kg; (2) fish species caught with their weights in kg; (3) number of traps; (4) length and width of the trap; (5) number of hours spent fishing and (6) number of fishers on the boat.

The fishers were also asked to indicate the locations of their traps. To this end, they were provided with the map, as shown in Figure 1, on which the space was divided into $1 \times 1 \mathrm{~km}$ grid blocks, numbered from 1 to 82 . The interviewer recorded the number and the position on the map. Data collected also included the characteristics of fishers and of their fishing technology, including trap size and the number of traps used.

One important consideration is that the spatial aggregation leads to a set of geographical areas, which would be one of the objects of choice in the fishers' decision-making process. When the individual areas become smaller, the number of choices increases. According to the Curtis and McConnell (2004), this corresponds to the short-run decision of fishers. As spatial areas are aggregated into larger blocks, so the choice eventually shifts from being a short-run decision to being a medium to long-term fishing location choice. The smaller the spatial aggregation and therefore the area, the less aggregation bias and the greater the ability to model realistic policy measures. However, the smaller the site, the less likely is that the spatial data will provide much information about the site (Curtis and McConnell 2004). Following Bockstael and Opaluch (1983), Eales and Wilen (1986), Dupont (1993) and Campbell and Hand (1999), the aggregation was done so as to ensure continuity of fishing effort in each fishing area; hence, eight areas were selected for the study. The characteristics of these areas are provided in Table 1. 
Fishing

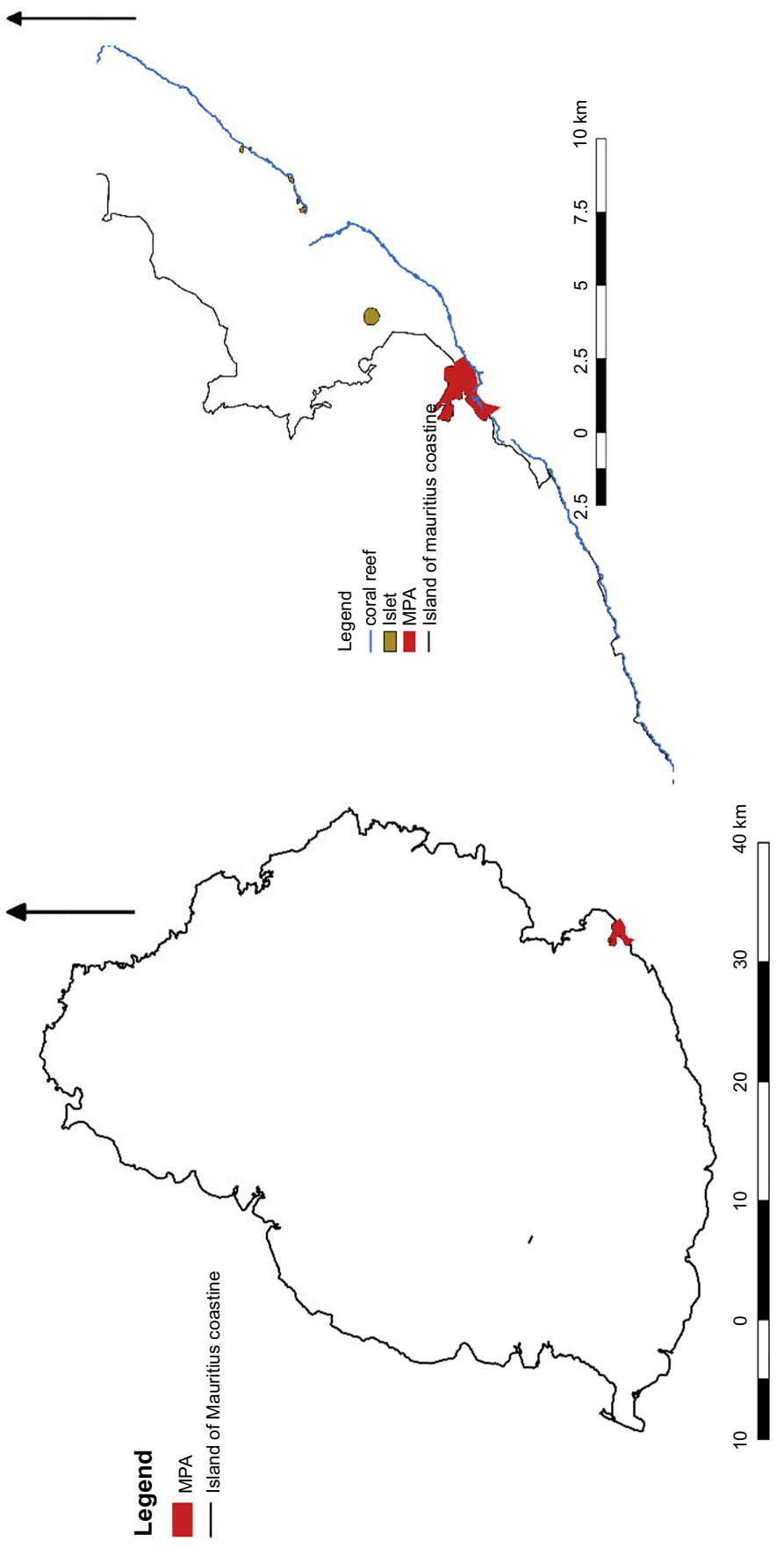

location choice and spatial behaviour

Figure 2. Map of Mauritius and study site 


\begin{tabular}{|c|c|c|c|c|c|c|}
\hline \multirow[b]{2}{*}{$\begin{array}{l}\text { MAEM } \\
4,1\end{array}$} & & & & & & \\
\hline & $\underline{\text { Variables }}$ & Definition & Mean & $\begin{array}{l}\text { Standard } \\
\text { deviation }\end{array}$ & Minimum & Maximum \\
\hline & $\mathrm{ECAT}_{j}$ & $\begin{array}{l}\text { Expected catch of the fisher } i \text { in the fishing } \\
\text { ground } j(\mathrm{~kg})\end{array}$ & 13.77 & 3.54 & 0 & 31.60 \\
\hline & $\mathrm{DIS}_{i j}$ & $\begin{array}{l}\text { Distance from the homeport of fisher } i \text { to the } \\
\text { fishing ground } j(\mathrm{~km})\end{array}$ & 8.38 & 3.37 & 1 & 18 \\
\hline 10 & $\mathrm{DEPTH}_{j}$ & Average depth in metres of the fishing & 16.17 & 7.80 & 5.30 & 26.6 \\
\hline & $\operatorname{SDCAT}_{i j}$ & $\begin{array}{l}\text { Standard deviation of the catch facing } \\
\text { fisher } i \text { in the fishing ground } j(\mathrm{~kg})\end{array}$ & 2.19 & 0.47 & 0.36 & 6.10 \\
\hline & $\mathrm{NBAS}_{i j}$ & $\begin{array}{l}\text { Number of traps of the fisher } i \text { used in the } \\
\text { fishing ground } j\end{array}$ & 8.19 & 1.70 & 1 & 13 \\
\hline $\begin{array}{l}\text { Variables and } \\
\text { definitions }\end{array}$ & $\operatorname{VBAS}_{j i}$ & $\begin{array}{l}\text { Size of traps of the fisher } i \text { used in the } \\
\text { fishing ground } j\left(\mathrm{~m}^{3}\right)\end{array}$ & 21.88 & 28.57 & 1.5 & 216 \\
\hline
\end{tabular}

During the survey, interviewers also carefully collected information using a map on the route that was taken by fishers during their trips. An important consideration is that fishers sometimes follow different routes to the same location. Care was thus taken to measure the distance along the route, which each fisher actually took to the destination. When a fisher did not stipulate a particular route for the non-chosen alternatives, the path used by another fisher from a nearby port was taken as a proxy.

Data on initial wealth were initially proxied by the size of the boat. However, during the estimation, the number and size of traps were strongly correlated with the size of the boat. The latter was then dropped the analysis.

\section{Results}

Random parameters logit estimation

Table 2 shows key information of the trips by fishing areas collected from the sample (refer to Figure 1 for the geographical location). Almost $85 \%$ of homeports of the fishers

\begin{tabular}{|c|c|c|c|c|}
\hline $\begin{array}{l}\text { Fishing } \\
\text { areas }\end{array}$ & $\begin{array}{l}\text { Distribution of } \\
\text { trips }(\%)\end{array}$ & $\begin{array}{l}\text { Average } \\
\text { catch per trip }\end{array}$ & $\begin{array}{l}\text { Standard } \\
\text { deviation of catch } \\
\text { rates }(\mathrm{kg})\end{array}$ & Other characteristics \\
\hline Area 1 & 3.7 & 13.7 & 8.55 & $\begin{array}{l}\text { Adjacent to the MPA and off lagoon } \\
\text { and high human risk }\end{array}$ \\
\hline Area 2 & 6.1 & 11.97 & 7.9 & $\begin{array}{l}\text { Situated partly in the lagoon and } \\
\text { partly off it and high human risk in } \\
\text { waters off the lagoon }\end{array}$ \\
\hline Area 3 & 2.5 & 17.88 & 9.08 & $\begin{array}{l}\text { High travelling cost and high human } \\
\text { risk }\end{array}$ \\
\hline Area 4 & 27.3 & 8.2 & 3 & $\begin{array}{l}\text { Low travelling cost and low human } \\
\text { risk }\end{array}$ \\
\hline Area 5 & 7.9 & 15.62 & 11.75 & $\begin{array}{l}\text { High travelling cost and high human } \\
\text { risk }\end{array}$ \\
\hline Area 6 & 26.8 & 12.81 & 5.02 & $\begin{array}{l}\text { Off lagoon but very productive reef } \\
\text { area }\end{array}$ \\
\hline Area 7 & 13.8 & 10.88 & 3.6 & $\begin{array}{l}\text { Low travelling cost and low human } \\
\text { risk }\end{array}$ \\
\hline Area 8 & 11.9 & 19.82 & 6.11 & Off lagoon and high travel cost \\
\hline
\end{tabular}

Table 2.

Distribution of trips and average catch per trip from survey
Area 8 
are located in the north of the MPA. The remaining homeports are located in the south around $4 \mathrm{~km}$ on average.

The estimates from the RPL model in Tables 3 and 4 seek to explain the distribution of trips in the eight fishing areas. To facilitate interpretation, Table 1 provides summary characteristics of the covariates.
Fishing

location choice and spatial behaviour

\section{1}

\begin{tabular}{lcc}
\hline & Coefficient (SE) & Coefficient (SE) \\
Variables & Model 1 & Model 2 \\
\hline ECAT $_{j}$ & $0.038(0.020)^{* * * *}$ & $0.202(0.024)^{* * * *}$ \\
DIS $_{j}$ & $-0.167(0.0239)^{* * *}$ & $-0.175(0.028)^{* * *}$ \\
DEPTH $_{j}$ & & $-0.144(0.011)^{* * *}$ \\
Random parameter $_{\text {SDCAT }}$ & & \\
SD of SDCAT $_{j}$ & $-2.702(0.757)^{* * * *}$ & $-2.953(0.826)^{* * *}$ \\
Number of observations & $7.926(0.899)^{* * *}$ & $9.512(1.137)^{* * * *}$ \\
LR $\chi^{2}(1)$ & 8,000 & 8,000 \\
Prob $>\chi^{2}$ & 1828.00 & 1903.61 \\
Log likelihood & 0.00 & 0.000 \\
Note & -1015.63 & -919.95
\end{tabular}

Note(s): SE $=$ standard error; $* * *=$ significant at $1 \%, * *=$ significant at $5 \%$ and $*=$ significant at $10 \%$

Random parameters logit model 1 and 2

\begin{tabular}{|c|c|c|}
\hline Variables & $\begin{array}{c}\text { Coefficient (SE) } \\
\text { Model } 3 \\
\end{array}$ & $\begin{array}{c}\text { Coefficient (SE) } \\
\text { Model } 4\end{array}$ \\
\hline $\begin{array}{l}\text { ECAT }_{j} \\
\text { DIS }_{i j} \\
\text { DEPTH }_{j} \\
\text { NBAS }_{i j} \times \mathrm{DUM}_{2} \\
\text { NBAS }_{i j} \times \mathrm{DUM}_{3} \\
\text { NBAS }_{i j} \times \mathrm{DUM}_{4} \\
\text { NBAS }_{i j} \times \mathrm{DUM}_{5} \\
\text { NBAS }_{i j} \times \text { DUM }_{6} \\
\text { NBAS }_{i j} \times \mathrm{DUM}_{7} \\
\text { NBAS }_{i j} \times \mathrm{DUM}_{8} \\
\text { VBAS }_{j i} \times \text { DUM }_{2} \\
\text { VBAS }_{j i} \times \text { DUM }_{3} \\
\text { VBAS }_{j i} \times \text { DUM }_{4} \\
\text { VBAS }_{j i} \times \text { DUM }_{5} \\
\text { VBAS }_{j i} \times \text { DUM }_{6} \\
\text { VBAS }_{j i} \times \text { DUM }_{7} \\
\text { VBAS }_{j i} \times \text { DUM }_{8}\end{array}$ & $\begin{array}{c}0.189(0.0269)^{* * * *} \\
-0.327(0.038)^{* * * *} \\
-0.067(0.066)^{* * *} \\
-0.067(0.0657) \\
-0.091(0.069) \\
-0.251(0.059)^{* * * *} \\
0.1017(0.107) \\
0.076(0.052) \\
0.131(0.080)^{*} \\
0.065(0.108) \\
-0.031(0.012)^{* * * *} \\
-0.025(0.001)^{* * *} \\
0.0015(0.009) \\
-0.0886(0.013)^{* * * *} \\
-0.0080(0.007) \\
-0.0390(0.007)^{* * *} \\
-0.094(0.017)^{* * * *}\end{array}$ & $\begin{array}{c}0.236(0.030)^{* * *} \\
-0.178(0.049)^{* * * *} \\
-0.115(0.074) \\
-0.166(0.074)^{* *} \\
-0.334(0.070)^{* * *} \\
0.039(0.119) \\
-0.024(0.059) \\
0.070(0.0876) \\
-0.019(0.119) \\
-0.021(0.0139) \\
-0.011(0.0102) \\
0.007(0.00954) \\
-0.070(0.0126)^{* * *} \\
-0.003(0.0076) \\
-0.029(0.0073)^{* * * *} \\
-0.093(0.0202)^{* * *}\end{array}$ \\
\hline $\begin{array}{l}\text { Random parameter } \\
\text { SDCAT }_{j} \\
\text { DIS }_{j} \\
\mathrm{SD}_{\text {of } \mathrm{SDCAT}_{j}} \\
\mathrm{SD} \mathrm{DIS}_{j} \\
\text { Number of observations } \\
\mathrm{LR}^{2}(1) \\
\text { Prob }>\chi^{2} \\
\text { Log likelihood }\end{array}$ & $\begin{array}{c}-3.140(0.952)^{* * * *} \\
9.200(1.12)^{* * *} \\
8,000 \\
1602.15 \\
0.00 \\
-773.529\end{array}$ & $\begin{array}{c}-3.143(0.8323)^{* * *} \\
-0.4128(0.0633)^{* * *} \\
10.288(0.9848) \\
0.556(0.0722) \\
8,000 \\
1720.78 \\
0.000 \\
-714.21\end{array}$ \\
\hline
\end{tabular}


MAEM

4,1

12

Model 1 in Table 3 introduces the calculated expected catch and distance as covariates. The standard deviation of catch is treated as the random variable. Importantly, the expected catch in an area is positively related to the likelihood that it is fished while the negative sign of the coefficient of the distance variable shows that the probability of choosing an area falls with distance from a fisher's homeport. This is consistent with studies such as Curtis and Hicks (2000), Mistiaen and Strand (2000) and Eggert and Tveteras (2004). The random parameter $\left(\mathrm{SDCAT}_{j}\right)$ has a negative coefficient and is statistically significant $(\phi<0.01)$. The negative coefficient is an indicator that fishers are typically risk-averse, i.e. the likelihood that an area will be fished falls with the variability of catches in it. The standard deviation of the variability of catch is also statistically significant supporting the hypothesis that the sensitivity of the catch variability varies among fishers. The most commonly used goodness of fit measure is the likelihood ratio test, with the null hypothesis that all parameters are equal to zero; the results show that this can be rejected at $99 \%$ confidence.

Model 2 in Table 3 adds the covariate $\mathrm{DEPTH}_{j}$. The coefficient is negative and is again statistically significant $(\phi<0.001)$. Deeper waters outside the reef that bounds the lagoon are regarded as riskier by artisanal fishers in small boats, consistent with Smith and Wilen (2005), Stelzenmüller et al. (2008) and Watson et al. (2018). The biophysical features of the ocean influence fishers' behaviour.

If fish density is given, two important determinants of the catch per trip are the number and size of the traps used. Accordingly, fishers' location choice is also influenced by these two factors. Table 4 shows the regression results after including the number of traps and the volumes of traps as attributes of individual fishers. The construction of individual-specific attributes follows Hoffman and Duncan (1988). Consider an attribute, $W_{i}$, of fisher, $i$, which is invariant across choices. Let $\mathrm{DUM}_{2}, \ldots, \mathrm{DUM}_{8}$ are the dummy variables for area 2-8, respectively. The attribute enters in the RPL model as follows: $W_{2} \mathrm{DUM}_{2}, \ldots W_{8} \mathrm{DUM}_{8}$, respectively, for the eight fishing areas. Area 1 is the base category. The coefficients give the effect of each attribute in each area relative to the omitted category.

Table 4 shows the results. The coefficient of "expected catch" remains positive and statistically significant in all models, i.e. a rise in expected catch increases the likelihood that a site will be fished. Model 4 treats distance as the random variable. From the lower part of the table, the coefficients of $\mathrm{SDCAT}_{j}$ and $\mathrm{DIS}_{i j}$ are highly statistically significant with the expected signs. The standard deviation of the two variables is also statistically significant, justifying their treatment as random variables in the regression.

To gauge the model's predictive ability, the estimated percentage of fishing effort in each fishing area is compared to the actual percentage shares (Table 5). The RPL estimates in Table 4 (model 4) are used for estimating the expected effort distribution. The shares differ by less than 0.03 points in 7 of the 8 fishing areas.

\section{Tabort distribution} actual versus simulated

Actual distribution of trip

Simulated distribution of trip

\begin{tabular}{lll}
\hline Area 1 & 0.04 & 0.04 \\
Area 2 & 0.06 & 0.04 \\
Area 3 & 0.03 & 0.05 \\
Area 4 & 0.27 & 0.30 \\
Area 5 & 0.08 & 0.05 \\
Area 6 & 0.27 & 0.21 \\
Area 7 & 0.14 & 0.17 \\
Area 8 & 0.12 & 0.15
\end{tabular}


Elasticities of changes in expected catch and variability

Table 6 shows the sensitivity of decisions regarding location to a $1 \%$ increase in expected catch in each fishing area. The italic figure in the table shows the elasticity of own effort to rising catch rate expectation; thus, a $1 \%$ increase in the expected catch rate in fishing areas 1 , 2 and 3 (the adjacent to the MPA) leads to increases of $1.8,1.4$ and $1.9 \%$, respectively, in the probabilities of fishers moving to these areas.

Effort in the remaining fishing areas also respond positively to rises in their own expected catch rate but the calculated elasticities are lower than those in the adjacent of the MPA. These effort elasticities warrant further explanation.

Areas 1, 2 and 3, being adjacent to the MPA, are also close to the shore, and only $10 \%$ of fishing effort is directed to them. Those who fish in these regions travelled at a distance of 5-6 km (Table 7). Why then, does the model suggest that fishing patterns are so responsive to yields in these areas? A plausible explanation can be obtained by referring to the remaining fishers who fish in the northern part of fishing ground. Most of these fishers have their homeports situated in the north of the fishing ground (refer to Figure 1) and have to travel long distances to reach areas 1,2 and 3. Since the travel cost has to be incurred before any catch is made, it is only when fishers are sure that they can cover the travel cost then they will decide to go to a particular site. Hence, a site may be highly preferred as soon as there is a slight increase in expected catch rate, which allows fishers to cover the travel cost. The estimates also suggest that effort at a site, which is easily accessible (for example area 4), will be less responsive to a change in the expected catch rate than the effort expended on a site where access entails high travelling costs.

The survey found that fishing area 4 attracted almost $27 \%$ of fishing effort. It has relatively lower travel cost compared to all areas with the exception of area 1 (see Table 7) because many fishers have their homeport to the north of the MPA and access is easy. It is observed that fishing effort is less sensitive to changes in the expected catch. This may be

\begin{tabular}{|c|c|c|c|c|c|c|c|c|c|}
\hline \multirow[b]{2}{*}{$1 \%$ rise in expected catch in } & \multirow[b]{2}{*}{ Area 1} & \multicolumn{7}{|c|}{$\%$ of change in probability that area will be selected } & \\
\hline & & Area 2 & Area 3 & Area 4 & Area 5 & Area 6 & Area 7 & Area 8 & \\
\hline Area 1 & 1.79 & -0.17 & -0.12 & -0.06 & -0.11 & -0.08 & -0.05 & -0.02 & \\
\hline Area 2 & -0.18 & 1.35 & -0.11 & -0.06 & -0.05 & -0.09 & -0.04 & -0.06 & \\
\hline Area 3 & -0.18 & -0.14 & 1.89 & -0.01 & -0.11 & -0.06 & -0.01 & -0.24 & \\
\hline Area 4 & -0.34 & -0.30 & -0.05 & 0.54 & -0.14 & -0.31 & -0.44 & -0.07 & Table 6. \\
\hline Area 5 & -0.17 & -0.09 & -0.15 & -0.05 & 1.34 & -0.13 & -0.07 & -0.12 & Elasticities of \\
\hline Area 6 & -0.34 & -0.37 & -0.18 & -0.26 & -0.30 & 1.22 & -0.31 & -0.23 & probability of location \\
\hline Area 7 & -0.17 & -0.11 & -0.03 & -0.28 & -0.14 & -0.24 & 1.11 & -0.08 & choices with respect to \\
\hline Area 8 & -0.13 & -0.31 & -0.94 & -0.07 & -0.34 & -0.28 & -0.13 & 1.06 & expected catch \\
\hline
\end{tabular}

\begin{tabular}{|c|c|c|c|c|c|}
\hline & Average distance travelled $(\mathrm{km})$ & Standard deviation & Minimum & Maximum & \\
\hline Area 1 & 4.81 & 2.88 & 1 & 12.5 & \\
\hline Area 2 & 6.44 & 2.57 & 3 & 14 & \\
\hline Area 3 & 6.52 & 2.71 & 1 & 10.7 & \\
\hline Area 4 & 5.05 & 1.26 & 2 & 10.5 & \\
\hline Area 5 & 7.96 & 3.69 & 2.1 & 17.8 & Table 7. \\
\hline Area 6 & 7.37 & 1.81 & 1 & 12 & Average distance \\
\hline Area 7 & 6.33 & 2.15 & 2 & 12.8 & travelled to fishing \\
\hline Area 8 & 10.01 & 3.01 & 1.1 & 16.8 & grounds \\
\hline
\end{tabular}

\section{Fishing \\ location choice and spatial \\ behaviour}

13 
MAEM

4,1

14

caused by congestion externalities given that fishers in the area are already many. The effects of such congestion on effort displacement are well documented (e.g. Curtis and Hicks, 2000; Poos et al., 2010; Girardin et al., 2017).

As the expected catch in one area rises, ceteris paribus, the probability of fishing in other regions will fall. The cross-elasticities are low, varying between 0.1 and 0.2 , indicating that a rise in the expected catch rate does not lead to a significant fall in fishing effort in other fishing areas. However, there is a certain degree of substitutability between areas 1, 2 and 3, all of which are adjacent to the MPA.

A rise in the expected catch in fishing area 4 attracts fishers from adjacent areas 1, 2, 6 and 7. Effort in all fishing areas appear highly responsive to the catch in fishing area 6 . One explanation is that area 6 is situated close to most of the other fishing areas. Fishing area 7 is a substitute to neighbouring areas 4 and 6 . Efforts in areas 4 and 6 are also highly responsive to catches in fishing area 8, which is adjacent to them. The closer are two areas, the higher the degree of substitutability between them.

The distance from the homeport to a fishing area has a negative effect on the probability that it will be fished. This relationship is consistent with similar studies, such as Stelzenmüller et al. (2008) and Valcic (2009), and is shown graphically in Figure 3.

Table 7 shows the average distances travelled to each fishing area by fishers. The average distance to fishing area 1, which is the nearest to the MPA area (area 1), is $4.8 \mathrm{~km}$. Fishing area 4 , which has the lowest catch rates but attract most fishers, has an average distance travelled of $5 \mathrm{~km}$. The difference between the two alternatives can be drawn from the other factors influencing fishing location choices, for example, the variability of catch.

Table 8 shows the change in the likelihood of choosing a particular fishing area with respect to a change in risk as measured by the standard deviation of catch.

Importantly, the effects of risk are not consistent across the eight areas. A rise in catch variability does not necessarily reduce the probability of fishing in that area. For instance, a $1 \%$ rise in catch variability in fishing area 1 leads to a fall in effort, not only in that area but also in areas 3 and 8 . When the same analysis is conducted for area 2 , a reduction in effort in areas 6 and 8 is observed. However, when the standard deviation of the catch widens in areas 2,3 and 8 , the number of fishers to these areas increases.

The explanation for the ambiguous result on the sensitivity of effort to standard deviation comes from the different attitude to risk of individual fishers. From Table 8, it is observed

Figure 3.

Distance and location choices from the RPL estimates

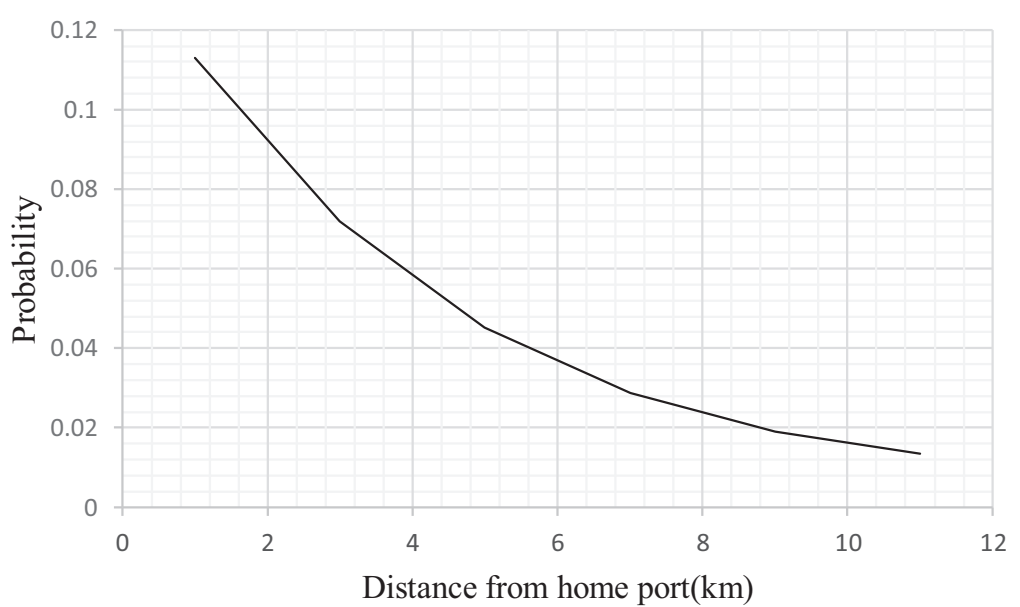


that, while the other areas attract risk-averse fishers, a $1 \%$ rise in the standard deviation of catch increases the probability that fishers will visit areas 2,3 , and 8 by $1.3,10.6$ and $3.4 \%$, respectively. In other words, areas 2, 3 and 8 tend to attract risk-loving fishers. While the other fishing areas are in the quiet waters protected by the Island's fringing reef, these areas are situated outside it, in the off-shore part of the fishing ground, an area that also carries greater physical risk.

Using the RPL model, the coefficient of the standard deviation of the expected catch can be used to differentiate fishers according to their risk preference. Almost 33\% of the fishers are classified as risk-loving (Figure 4). The fishers' attitudes have implications for the displacement of effort, since the reactions of risk-averse fishers differ from those of risklovers.

\section{Marginal rates of substitution between drivers of fishing location and catch rate expectation}

Since the underlying utility function assumed in this study is linear in its explanatory variables, the marginal rates of substitution (MRS) between the drivers of fishing effort appear in terms of the catch rate (Buracam et al., 2013). The MRS for distance quantifies how much catch per trip (in $\mathrm{kg}$ ) would be needed to maintain the same level of fishing activity if there is an increase in the average travel distance of $1 \mathrm{~km}$. The result shows

\begin{tabular}{|c|c|c|c|c|c|c|c|c|c|}
\hline \multicolumn{10}{|c|}{$\%$ of change in probability to choose the respective fishing ground } \\
\hline $1 \%$ rise in $\mathrm{SD}$ of catch & Area 1 & Area 2 & Area 3 & Area 4 & Area 5 & Area 6 & Area 7 & Area 8 & \\
\hline Area 1 & -2.57 & 0.02 & -0.29 & 1.40 & 0.39 & 0.51 & 0.70 & -0.26 & \\
\hline Area 2 & 0.01 & 1.30 & -0.66 & 0.42 & 0.04 & -0.26 & 0.12 & -1.09 & \\
\hline Area 3 & -0.21 & -0.69 & 10.61 & -0.17 & -0.49 & -0.82 & -0.09 & -6.47 & \\
\hline Area 4 & 0.16 & 0.06 & -0.03 & -2.31 & 0.16 & 0.62 & 1.36 & -0.09 & Table 8. \\
\hline Area 5 & 0.25 & 0.03 & -0.36 & 0.73 & -1.14 & 0.38 & 0.40 & -0.55 & Elasticities of \\
\hline Area 6 & 0.09 & -0.08 & -0.22 & 1.04 & 0.14 & -1.03 & 0.55 & -0.71 & probability of location \\
\hline Area 7 & 0.17 & 0.03 & -0.03 & 3.02 & 0.19 & 0.68 & -3.77 & -0.19 & choices with respect to \\
\hline Area 8 & -0.05 & -0.30 & -1.87 & -0.11 & -0.18 & -0.68 & -0.13 & 3.35 & catch variability \\
\hline
\end{tabular}

Fishing location choice and spatial behaviour

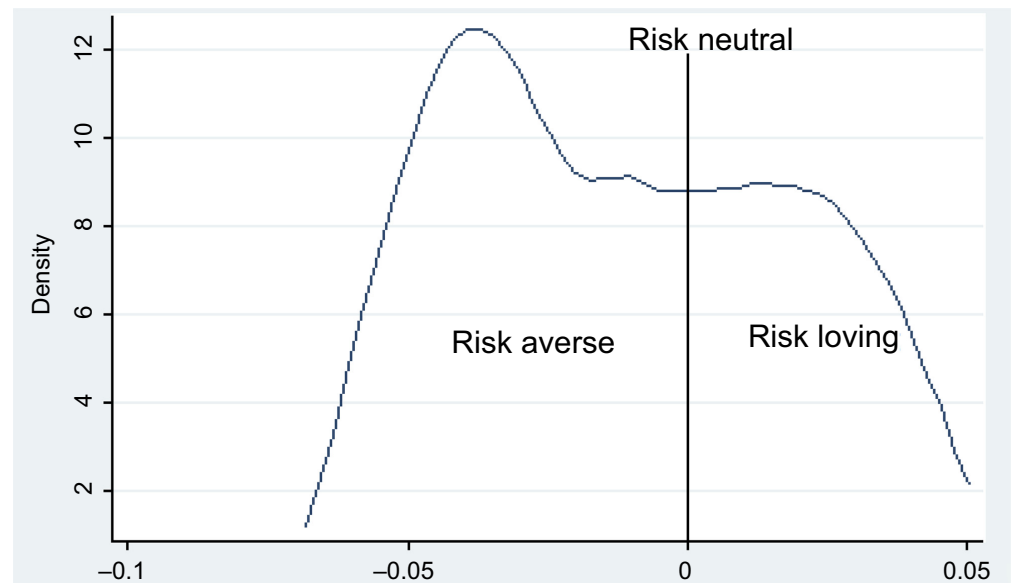

Figure 4. Risk preference of fishers 
MAEM

4,1

\section{6}

that $1.7 \mathrm{~kg}$ is required [3]. The MRS with respect to depth measured in metres stand at $0.8 \mathrm{~kg}$.

When fishers face a one unit increase in standard deviation of catch per trip in a particular location, they will require a compensation of $13.3 \mathrm{~kg}$ on average to keep fishing there. However, the rate of substitution is an average that ignores the variation in risk aversion between fishers.

\section{Modelling the impacts of marine closure on spatial effort distribution}

A key issue in the design of marine reserves is effort displacement. Where do fishers go when an area is closed to them? Using the estimates from the RPL, it can be shown where displaced fishers would go if any of the eight areas studies were closed to fishing.

Table 9 shows that closing a high fishing intensity area such as area 4 leads to a significant increase in fishing effort in areas 6 and 7 , while the closure of area with low fishing pressure (area 1, 2 and 3) leads to a marginal change in other fishing areas.

The analysis shows that expanding the locally reserved area by closing any of the eight areas studied would tend to shift the effort in the direction of the areas closer to the local fishing port inshore, i.e. 4, 6, 7 and 8.

\section{Conclusion}

This study attempts to shed light on the fishing the line hypothesis and supports the view that rising catch rates will attract fishers at the border of a Marine Park BBMP. However, the elasticity of fishers' effort with respect to expected catch differs across the areas, including the adjacent of the Park. Importantly, the responsiveness of effort to the catch rate is lowest in areas which are already heavily fished and easily accessible. A probable explanation relates to congestion effects of being accessible. As fishers anticipate the areas would be overcrowded, this acts as a deterrent to respond to rising expected catch rates. In contrast, the adjacent areas of the MPA are less accessible from most fishers whose homeports are located in the northern part of the fishing ground, and therefore the effort exhibits high responsiveness to rising catch rates. Rising expectations on catch rates in this case attract fishers who are more likely to cover their travel costs. The high elasticity implies that even if a reserve is placed in highly inaccessible area, involving high travel cost, as soon as expectations of catch rates rise (through spillovers), it may attract fishers in its vicinity, leading to degradation in the adjacent areas. A small reserve, in this respect, may be desirable as it is more likely to bring about minimal spillovers, and therefore would not attract many fishers. This design would be appropriate if the policy objective of the MPA is to shift fishers to other substitute areas.

The study also demonstrates that even if there is evidence that fishers have been fishing the line from the MPA, there are also other factors which affect fishermen choice of fishing

Table 9.

Redistribution of fishing effort with marine closure

\begin{tabular}{|c|c|c|c|c|c|c|c|c|c|}
\hline & Status quo & Area 1 & Area 2 & Area 3 & Area 4 & Area 5 & Area 6 & Area 7 & Area 8 \\
\hline Area 1 & 0.04 & 0 & 0.04 & 0.04 & 0.06 & 0.05 & 0.04 & 0.04 & 0.04 \\
\hline Area 2 & 0.05 & 0.05 & 0 & 0.05 & 0.08 & 0.05 & 0.06 & 0.05 & 0.06 \\
\hline Area 3 & 0.04 & 0.04 & 0.04 & 0 & 0.04 & 0.05 & 0.05 & 0.04 & 0.10 \\
\hline Area 4 & 0.32 & 0.33 & 0.34 & 0.32 & 0 & 0.33 & 0.40 & 0.40 & 0.33 \\
\hline Area 5 & 0.06 & 0.07 & 0.07 & 0.07 & 0.07 & 0 & 0.08 & 0.07 & 0.08 \\
\hline Area 6 & 0.18 & 0.19 & 0.19 & 0.19 & 0.26 & 0.20 & 0 & 0.22 & 0.22 \\
\hline Area 7 & 0.15 & 0.15 & 0.15 & 0.15 & 0.31 & 0.16 & 0.19 & 0 & 0.16 \\
\hline Area 8 & 0.16 & 0.16 & 0.17 & 0.18 & 0.18 & 0.18 & 0.20 & 0.17 & 0 \\
\hline
\end{tabular}


grounds. Thus, even if the catch rates are high relative to other fishing areas, as only $10 \%$ of local fishing trips are in the vicinity. Whilst higher catches do attract fishers, they are only a partial and very restrictive explanation of fishers' behaviour. Fishers evaluate several factors before choosing their preferred fishing sites. Distance from the homeport, variance of catch at a site and fishers' attitudes to risk play an important role in determining fishers' effort should also be considered in the configuration of an MPA.

The RPL model generates the marginal rate of substitution between the drivers of fishers' effort and catch rate expectations. This enables the estimation of costs that fishers would incur following closure. An indifference curve, drawn with distance travelled on one axis and expected catch on the other, would have a positive slope of 1.7, representing the compensation of fishers following a rise in distance, so that they are not worst off.

The study shows that the Blue Bay region has several fishing areas which would be especially sensitive to further marine closure in terms of effort distribution, particularly vulnerable ones being those that provide stable catches and are close to fishers' homeports.

The finding has an important implication on the size of an MPA. The establishment of a MPA has important implications on fishermen relocation of efforts and therefore affects the broader costs and benefits of the reserve. In this respect, the analytical framework and estimation method of this study allow the identification of fishing areas as complements (when fishing in one area increases fishing effort in another) and substitute which is valuable information for both determining the placement and size of an MPA. The analysis suggested that the zones most likely to have suffered from the closure of an area would have been those substitute areas that offered fishers low travel costs, stable catches and a lower potential human risk. If a reserve is placed in a preferred fishing area and is large, the resulting spatial redistribution of fishers may have profound effects on fish populations in other substitute areas. A larger reserve is likely to have more displacement effect in this case than a smaller one. Therefore, a small or a network of a small reserve may be appropriate. The premise to select the site and size of the reserve is to avoid overconcentration of fishers in alternative fishing areas, which can be vulnerable to excessive fishing and unintended effects from fishers.

\section{Limitations of the study}

The lack of evidence on fishing the line can also be attributed to limited spillovers when there is no suitable habitat outside an MPA for adult fish or for larvae to settle. Biological and ecological research on spillovers in the study site would supplement the findings of this study. Drivers such as spatial behaviour such as past behaviour, tradition and information sharing were also not treated in this analysis. The analysis can be improved through a much in-depth analysis of fishers' location choice, combining several research designs, quantitative as well as qualitative, that could be replicated in many small scale fisheries.

The simulations of spatial fishery closure in this study used static economic analysis which neither allowed for the dynamic increases or decreases in the fishable stock following spatial closure nor for potential changes in economic factors such as fish prices. The build-up of biomass can take several years, and spillover effect is time dependent. Since the Marine Park has been established for more than three decades ago, the results are sufficiently informative in relation to the distribution of fishing efforts and determinants of fishing location choices.

\section{Notes}

1. This technique is used in this study, and further information is provided in the next section.

\section{Fishing location choice and spatial behaviour}


MAEM

4,1

18

2. A detailed explanation of RPL can be found in Train (2009)

3. The MRS between expected catch and distance, $\frac{\partial \mathrm{ECAT}}{\partial \mathrm{DIS}}$, is calculated as follows: $-\frac{\partial U}{\partial \mathrm{DIS}} / \frac{\partial U}{\partial \mathrm{ECAT}}$. The coefficient of the covariate DIS (-0.33) and ECAT (0.19) are used. This gives 1.7.

\section{References}

Abbott, J.K. and Wilen, J.E. (2011), "Dissecting the tragedy: a spatial model of behavior in the commons”, Journal of Environmental Economics and Management, Vol. 62 No. 3, pp. 386-401.

Abernethy, K.E., Allison, E.H., Molloy, P.P. and Côté, I.M. (2007), "Why do Fishers fish where they fish? Using the ideal free distribution to understand the behaviour of artisanal reef Fishers", Canadian Journal of Fisheries and Aquatic Sciences, Vol. 64 No. 11, pp. 1595-1604, doi: 10.1139/ F07-125.

AFRC (2008), “Albion fisheries research centre”, Annual Report, Ministry of Agro-Industry, Food Production and Security, Port-Louis.

Andersen, B.S., Ulrich, C., Eigaard, O.R. and Christensen, A. (2012), "Short-term choice behaviour in a mixed fishery: investigating metier selection in the Danish gillnet fishery", ICES Journal of Marine Science, Vol. 69 No. 1, pp. 131-143, Buracam et al., 2013.

Bellier, E., Neubauer, P., Monestiez, P., Letourneur, Y., Ledireach, L., Bonhomme, P. and Bachet, F. (2013), "Marine reserve spillover: modelling from multiple data sources", Ecological Informatics, Vol. 18 November, pp. 188-193.

Berman, M. (2006), "Modeling spatial choice in ocean fisheries”, Marine Resource Economics, Vol. 21 No. 4, pp. 375-394.

Bhagooli, R. and Kaullysing, D. (2018), Chapter 12 Seas of Mauritius. World Seas: An Environmental Evaluation, 2nd ed., The Indian Ocean to the Pacific, Academic Press, Vol. II, doi: 10.1016/B9780-08-100853-9.00016-6.

Bingham, M.F., Li, Z., Mathews, K.E., Spagnardi, C.M., Whaley, J S., Veale, S.G. and Kinll, J. (2011), “An application of behavioral modeling to characterize urban angling decisions and values”, North American Journal of Fisheries Management, Vol. 31 No. 2, pp. 257-268.

Bockstael, N.E. and Opaluch, J.J. (1983), "Discrete modellling of supply response under uncertainty: the case of the fishery", Journal of Environmental Economics and Management, Vol. 10 No. 2, pp. 125-137.

Brick, K., Visser, M. and Burns, J. (2012), "Risk aversion: experimental evidence from South African fishing communities”, American Journal of Agricultural Economics, Vol. 94 No. 1, pp. 133-152.

Buracam, S.J., White, J.W., Sanchirico, J.N. and Wilen, J.E. (2013), "Behavior of the Galapagos fishing fleet and its consequences for the design of spatial management alternatives for the red spiny lobster fishery”, Ocean and Coastal Management, Vol. 78 June, pp. 88-100.

Campbell, H.F. and Hand, A.J. (1999), "Modeling the spatial dynamics of the U.S. purse-seine fleet operating in the western Pacific tuna fishery", Canadian Journal of Fisheries and Aquatic Science, Vol. 56 No. 7, pp. 1266-1277.

Cabral, R.B., Gaines, S.D., Johnson, B.A., Bell, T.W. and White, C. (2017), "Drivers of redistribution of fishing and non-fishing effort after the implementation of a marine protected area network", Ecological Applications, Vol. 27 No. 2, pp. 416-428.

CBD (2016), "Secretariat of the convention on biological diversity. Ecologically or biologically significant marine areas (EBSAs)", Special Places in the World's Oceans, Southern Indian Ocean, Vol. 3, p. 128.

Chapman, M.R. and Kramer, D.L. (1999), "Gradients in coral reef fish density and size across the Barbados marine reserve boundary: effects of reserve protection and habitat characteristics”, Marine Ecology Progress Series, Vol. 181, pp. 81-96. 
Christensen, A.S. and Raakjær, J. (2006), "Fishermen's tactical and strategic decisions: a case study of Danish demersal fisheries", Fisheries Research, Vol. 81 Nos 2-3, pp. 258-267.

Conand, C., Basant Rai, Y., Hurbungs, M.D., Koojul, M., Paupiah, C.N., Chooreshwar, R.D. and Quod, J. (2016), "Distribution of holothurians in the shallow lagoons of two marine parks of Mauritius", SPC Beche-de-mer Information Bulletin, Vol. 36 March, pp. 15-19.

Curtis, R. and Hicks, R.L. (2000), "The cost of sea turtle preservation: the case of Hawaii's pelagic longliners", American Journal of Agricultural Economics, Vol. 82 No. 5, pp. 1191-1197.

Curtis, R.E. and McConnell, K.E. (2004), "Incorporating information and expectations in fishermen's spatial decisions", Marine Resource Economics, Vol. 18 No. 1, pp. 131-143.

Dabrowska, K., Hunt, L.M. and Haider, W. (2017), "Understanding how angler characteristics and context influence angler preferences for fishing sites", North American Journal of Fisheries Management, Vol. 37 No. 6, pp. 1350-1361.

Daw, T.M. (2008), "Spatial distribution of effort by artisanal fishers: exploring economic factors affecting the Lobster fisheries of the Corn Islands, Nicaragua", Fisheries Research, Vol. 90 Nos 1,3, pp. 17-25.

Dupont, D.P. (1993), "Price uncertainty, expectations formation and Fishers' location choices", Marine Resource Economics, Vol. 8 No. 3, pp. 219-46.

Eales, J. and Wilen, J.E. (1986), "An examination of fishing location choice in the pink shrimp fishery", Marine Resource Economics, Vol. 2 No. 4, pp. 331-351.

Eggert, H. and Lokina, R. (2007), "Small-scale fishermen and risk preferences", Marine Resource Economics, Vol. 22 No. 1, pp. 49-67.

Eggert, H. and Martinsson, P. (2004), "Are commercial Fishers risk lovers?", Land Economics, Vol. 80 No. 4 , pp. 550-60.

Eggert, H. and Tveterås, R. (2004), "Stochastic production and heterogeneous risk preferences: commercial Fishers' gear choices", American Journal of Agricultural Economics, Vol. 86 No. 1, pp. 199-212.

Forcada, A., Valle, C., Bonhomme, P., Criquet, G., Caglou, G., Lenfant, P. and Sánchez-Lizaso, J.L. (2009), "Effects of habitat on spillover from marine protected areas to artisanal fisheries", Marine Ecology Progress Series, Vol. 379, pp. 197-211.

Gell, F.R. and Roberts, C.M. (2003), "Benefits beyond boundaries: the fishery effects of marine reserves", Trends in Ecology and Evolution, Vol. 18 No. 9, pp. 448-455.

Gillis, D.M. and Lee, V. (2012), "Advancing the application of the ideal free distribution to spatial models of fishing effort: the isodar approach", Canadian Journal of Fisheries and Aquatic Sciences, Vol. 69 No. 10, pp. 1610-1620, doi: 10.1139/f2012-091.

Gillis, D.M., Peterman, R.M. and Tyler, A.V. (1992), "Movement dynamics in a fishery: application of the ideal free distribution to spatial allocation of effort", Canadian Journal of Fisheries and Aquatic Sciences, Vol. 50 No. 2, p. 11.

Girardin, R., Hamon, K.G., Pinnegar, J., Poos, J.J., Thebaud, O., Tidd, A., Vermard, Y. and Marchal, P. (2017), "Thirty years of fleet dynamics modelling using discrete-choice models: what have we learned?", Fish and Fisheries, Vol. 18 No. 4, pp. 638-655.

Gordon, S.H. (1954), "The economic theory of a common-property resource: the fishery", The Journal of Political Economy, Vol. 62 No. 2, pp. 124-142.

Halpern, B.S. (2003), “The impact of marine reserves: do reserves work and does reserve size matter?", Ecological Application, Vol. 13 No. 1, pp. 117-137.

Herrero, I. and Pascoe, S. (2003), "Value versus volume in the catch of the Spanish south-atlantic trawl fishery”, Journal of Agricultural Economics, Vol. 54 No. 2, pp. 325-341.

Hoffman, S. and Duncan, G. (1988), "What are the economic consequences of divorce?", Demography, Vol. 25 No. 4, pp. 641-645. 
MAEM

4,1

Holland, D.S. (2000), "A bioeconomic model of marine sanctuaries on Georges Bank", Canadian Journal of Fisheries and Aquatic Sciences, Vol. 57 No. 6, pp. 1307-1319.

Holland, D.S. and Sutinen, J.G. (2000), "Location choice in new England trawl fisheries: old habits die hard”, Land Economics, Vol. 76 No. 1, pp. 133-149.

Hopf, J.K., Jones, G.P., Williamson, D.H. and Connolly, S.R. (2016), "Fishery consequences of marine reserves: short-term pain for longer-term gain”, Ecological Application, Vol. 26 No. 3, pp. 818-829.

Hutton, T., Mardle, S., Pascoe, S. and Clark, R.A. (2004), "Modelling fishing location choice within mixed fisheries: English North Sea beam trawlers in 2000 and 2001", ICES Journal of Marine Science, Vol. 61 No. 8, pp. 1443-1452.

Just, R. and Pope, R.D. (1979), "Production function estimation and related risk considerations", Vol. 61 No. 2, pp. 276-284.

Kamil, K.A., Hailu, A., Rogers, A. and Pandit, R. (2017), "An assessment of marine protected areas as a marine management strategy in Southeast Asia: a literature review", Ocean and Coastal Management, Vol. 145 No. 1, pp. 72-81.

Kelleher, K. (2017), "Fishries and aquanculture and the ocean economy", in Cervigni, R. and Scandizzo, P.L. (Eds), The Ocean Economy in Mauritius Making it Happen, Making it Last, World Bank Group, pp. 103-153.

Kellner, J.B., Tetreault, I., Gaines, S.D. and Nisbe, R.M. (2007), "Fishing the line near marine reserves in single and multispecies fisheries”, Ecological Applications, Vol. 17 No. 4, pp. 1039-1054.

Lloret, J., Cowx, I.G., Cabral, H., Castro, M., Font, T., Gonçalves, J.M.S., Gordoa, A., Hoefnagel, E., Matić-Skoko, S., Mikkelsen, E., Morales-Nin, B., Moutopoulos, D.K., Muñoz, M., Neves dos Santos., M., Pintassilgo, P., Pita, C., Stergioun, K.I., Ünal, V., Veiga, P. and Erzini, K. (2018), "Small-scale coastal fisheries in European Seas are not what they were: ecological, social, and economic changes", Marine Policy, Vol. 98 December, pp. 176-186.

Lorenzen, K., Steneck, R.S., Warner, R.R., Parma, A.M., Coleman, F.C. and Leber, K.M. (2010), "The spatial dimensions of fisheries putting it all in place”, Bulletin of Marine Science, Vol. 86 No. 2, pp. 169-177.

McFadden, D. (1974), Conditional Logit Analysis of Qualitative Choice Behavior in Frontier in Econometrics, in Zarembka, P., (Ed), New York, NY, Academic Press, pp. 105-142.

Mistiaen, J.A. and Strand, I.E. (2000), "Supply response under uncertainty with heterogeneous risk preferences: location choice in longline fishing", American Journal of Agricultural Economics, Vol. 82 No. 5, pp. 1184-1190.

Norse, E.A. (2010), "Ecosystem-based spatial planning and management of marine fisheries: why and how", Bulletin of Marine Science, Vol. 86 No. 2, pp. 179-195.

Pérez-Ruzafa, A., Garcia-Charton, J.A. and Marcos, C. (2017), "North east atlantic vs. Mediterranean marine protected areas as fisheries management tool", Frontiers in Marine Science, Vol. 4 No. 245 , pp. 1-22.

Poos, J.J., Quirijns, F.J. and Rijnsdorp, A.D. (2010), "Spatial segregation among fishing vessels in a multispecies fishery", ICES Journal of Marine Science, Vol. 67 No. 1, pp. 155-164.

Pradhan, N.C. and Leung, P. (2004), "Modeling trip choice behavior of the longline Fishers in Hawaii", Fisheries Research, Vol. 68, pp. 209-224.

Republic of Mauritius (2010), Oceanographic Survey Report - Blue Bay Area, Delphinium Mauritius, Quatre Bornes.

Salas, S. and Gaertner, D. (2004), "The behavioural dynamics of Fishers: management implications”, Fish and Fisheries, Vol. 5 No. 2, pp. 153-167.

Smith, M.D. (2000), "Spatial search and fishing location choice: methodological challenges of empirical modelling", American Journal of Agricultural Economics, Vol. 82 No. 5, pp. 1198-1206. 
Smith, M.D. (2004), "Fishing yield, curvature and spatial behaviour: implications for modelling marine reserves", Natural Resource Modeling, Vol. 17 No. 3, pp. 273-298.

Smith, M.D. (2010), "Toward an econometric foundation for marine ecosystem-based management", Bulletin of Marine Science, Vol. 86 No. 2, pp. 461-477.

Smith, M.D. and Wilen, J.E. (2003), "Economic impacts of marine reserves: the importance of spatical behaviour", Journal of Environmental Economics and Management, Vol. 46, pp. 183-206.

Smith, M.D., Zhang, J. and Coleman, F.C. (2006), "Effectiveness of marine reserves for large-scale fisheries management", Canadian Journal of Fisheries and Aquatic Sciences, Vol. 63 No. 1, pp. 153-164.

Smith, M.D. and Wilen, J.E. (2005), "Heterogeneous and correlated risk preferences in commercial fishermen: the perfect storm dilemma", The Journal of Risk and Uncertainty, Vol. 31 No. 1, pp. 53-71.

Stelzenmüller, V., Maynou, F., Bernard, G., Cadiou, G., Camilleri, M., Crec’hriou, R., Criquet, G., Dimech, M., Esparza, O., Higgins, R., Lenfant, P. and Pérez-Ruzafa, A. (2008), "Spatial assessment of fishing effort around European marine reserves: implications for successful fisheries management”, Marine Pollution Bulletin, Vol. 56 No. 12, pp. 2018-2026.

Tidd, A., Hutton, T., Kell, L.T. and Blanchard, J. (2012), "Dynamic prediction of effort reallocation in mixed fisheries", Fisheries Research, Vols 125-126, pp. 243-253, doi: 10.1016/j.fishres.2012. 03.004 .

Train, K. (2009), Discrete Choice Methods with Simulation, Cambridge University Press, New York.

UNDP (2012), Blue Bay Marine Park Management Plan, Ministries of Fisheries and Rodrigues Republic of Mauritius, Port-Louis.

Valcic, B. (2009), "Spatial policy and the behaviour of fishermen", Marine Policy, Vol. 33 No. 2, pp. 215-222.

van der Lee, A., Gillis, D.M. and Hurley, P. (2013), "Fishing the line: catch and effort distribution around the seasonal haddock (Melanogrammus aeglefinus) spawning closure on the Scotian Shelf", Canadian Journal of Fisheries and Aquatic Sciences, Vol. 70 No. 3, pp. 973-981, doi: 10. 1139/cjfas-2012-0341.

Van Putten, I.E., Kulmala, S., Thebaud, O., Dowling, N., Hamon, K.G., Hutton, T. and Pascoe, S. (2012), "Theories and behavioural drivers underlying feet dynamics models", Fish and Fisheries, Vol. 13 No. 2, pp. 216-235.

Watson, J.R., Fuller, E.C., Castruccio, F.S. and Samhouri, J.F. (2018), "Fishermen follow fine-scale physical ocean features for finance", Frontier Marine Science, Vol. 5 No. 46, pp. 1-13.

Wilen, J.E. (1976), "Common property resources and the dynamics of over-exploitation: the case of the North-Pacific fur seal”, Paper n ${ }^{\circ} 3$ in the Programme in Resource Economics, Department of Economics, The University of British Columbia, Vancouver.

Wilen, J.E., Smith, M.D., Lockwood, D. and Botsford, L.W. (2002), "Avoiding surprises: incorporating fisherman behavior into management models", Bulletin of Marine Science, Vol. 70 No. 2, pp. 553-576.

\section{Further reading}

Hanemann, M. (1984), "Welfare evaluations in contingent valuation experiments with discrete responses", American Journal of Agricultural Economics, Vol. 66 No. 3, pp. 332-341.

Hilborn, R. (2007), "Managing fisheries is managing people: what has been learned?", Fish and Fisheries, Vol. 8, pp. 285-296.

Lopes, P.F.M. and Begossi, A. (2011), "Decision-making processes by small-scale fishermen on the southeast coast of Brazil", Fisheries Management and Ecology, Vol. 18 No. 5, pp. 400-410. 
MAEM

4,1

22
Sultan, M.A.R. (2019), Marine Protected Areas in the Management of Artisanal Fisheries, $\mathrm{PhD}$ Thesis, University of Cape Town, Cape Town, pp. 26-07, available at: https:/open.uct.ac.za/handle/ $11427 / 30334$.

\section{Corresponding author}

Riad Mohammed Sultan can be contacted at: r.sultan@uom.ac.mu

For instructions on how to order reprints of this article, please visit our website: www.emeraldgrouppublishing.com/licensing/reprints.htm Or contact us for further details: permissions@emeraldinsight.com 